\title{
Synthesis, spectroscopic and structural characterization of new linear mononuclear silver(I) complexes containing $\alpha$-keto phosphorus ylides as ambidentate ligands
}

\author{
SEYED JAVAD SABOUNCHEI ${ }^{\mathrm{a}, *}$, MOHSEN AHMADI $^{\mathrm{a}}$, FATEMEH AKHLAGHI $^{\mathrm{a}}$ \\ and HAMID REZA KHAVASI ${ }^{\mathrm{b}}$ \\ ${ }^{a}$ Faculty of Chemistry, University of Bu-Ali Sina, Hamedan, 65174, Iran \\ ${ }^{b}$ Department of Chemistry, Shahid Beheshti University, G.C., Evin, Tehran, 1983963113, Iran \\ e-mail: jsabounchei@yahoo.co.uk
}

MS received 23 May 2012; revised 29 September 2012; accepted 11 October 2012

\begin{abstract}
The reaction of 2 equiv. phosphorus ylides, $\left(\mathrm{C}_{6} \mathrm{H}_{5}\right)_{3} \mathrm{PCHC}(\mathrm{O}) \mathrm{C}_{6} \mathrm{H}_{4} \mathrm{R}\left(\mathrm{R}=\mathrm{CH}_{3}(\mathbf{L 1}), \mathrm{Br}(\mathbf{L 2}), \mathrm{Cl}\right.$ (L3), $\mathrm{NO}_{2}$ (L4) and $\mathrm{OCH}_{3}(\mathbf{L 5})$ ) with 1 equiv. $\mathrm{AgNO}_{3}$ using methanol as solvent leads to formation of linear mononuclear Ag-CH complexes, [ $\left.\left\{\mathrm{RC}_{6} \mathrm{H}_{4} \mathrm{CO}\left\{\left(\mathrm{C}_{6} \mathrm{H}_{5}\right)_{3} \mathrm{P}\right\} \mathrm{CH}\right\}_{2} \mathrm{Ag}\left(\mathrm{NO}_{3}\right)\right],\left(\mathrm{R}=\mathrm{CH}_{3}(\mathbf{C 1}), \mathrm{Br}(\mathbf{C 2}), \mathrm{Cl}(\mathbf{C} 3)\right.$, $\mathrm{NO}_{2}(\mathbf{C 4})$ and $\mathrm{OCH}_{3}(\mathbf{C 5})$ ), which contain one $\mathrm{NO}_{3}$ and two phosphorus ylides coordinated via the ylidic carbon atom. The silver complexes were synthesized and investigated by elemental analysis, Fourier transform infrared spectroscopy (FTIR), multinuclear $\left({ }^{1} \mathrm{H},{ }^{31} \mathrm{P}\right.$ and ${ }^{13} \mathrm{C}$ ) Nuclear magnetic resonance (NMR). In addition, the identities of complexes $\mathbf{C 1}$ and $\mathbf{C 3}$ were unequivocally determined by single crystal X-diffraction techniques. X-ray single crystal diffraction studies show that both complexes $\mathbf{C 1}$ and $\mathbf{C 3}$ belong to the triclinic crystal system and $P-1$ space group. This crystal packing of structures shows a close association between the nitrate anion and the metal centre. The $\operatorname{Ag}(\mathrm{I})$ atom is located in a slightly distorted linear environment, surrounded by $\mathbf{C}$ atoms of the methine of the ylide.
\end{abstract}

Keywords. Phosphorus ylide; coordination mode; ambidentate ligand; mononuclear silver(I) complexes.

\section{Introduction}

The utility of metalated phosphorus ylides in synthetic chemistry has been well-documented. ${ }^{1,2}$ Synthesis of complexes derived from ylides and Ag(I) began in 1975 by Yamamoto et al. ${ }^{3}$ Other types of ylide complexes of silver(I) have also been reported. ${ }^{4-9}$ In 1987 and 1993, Vicente et al. ${ }^{10,11}$ reported crystal structures of $\mathrm{Ag}(\mathrm{I})$ complexes of phosphorus ylides. The $\alpha$-keto-stabilized phosphorus ylides $\mathrm{R}_{3} \mathrm{E}=\mathrm{C}\left(\mathrm{R}^{\prime}\right) \mathrm{COR}^{\prime \prime}\left(\mathrm{E}=\mathrm{P}, \mathrm{As} ; \mathrm{R}, \mathrm{R}^{\prime}\right.$, $\mathrm{R}^{\prime \prime}=\mathrm{H}$, alkyl or aryl groups) show high stability (which allow them to be easily handled in air) and ambidentate character as ligands (C- versus $\mathrm{O}$-coordination). This ambidentate character can be rationalized in terms of resonance forms $\mathbf{a}-\mathbf{c}$ (where $\mathbf{c}$ is represented by the cis and trans geometrical isomers).<smiles>[R15]C([R7])=C([R7])C</smiles>

a<smiles>[R]C(=O)C([R])([R5])[O-]</smiles>

b<smiles>[R]C([R4])=C([R])[O-]</smiles>
or<smiles>[R]C([R5])=C([R])[O-]</smiles>

c

Forms $\mathbf{b}$ and $\mathbf{c}$ account for the metal $\mathbf{C}$-coordination $\mathbf{A}$ and O-coordination $\mathbf{B}$ (in cis and trans forms), respectively.<smiles></smiles>

A<smiles>[M]OC([R])=C([R16])[R]</smiles>

Cisoid<smiles>[R]C([R15])=C([R])O[Na]</smiles>

B

Transoid

*For correspondence 
Although many coordination modes are possible for keto ylides, ${ }^{12}$ coordination through carbon is dominant in soft metal ions, e.g., $\mathrm{Pd}(\mathrm{II}), \mathrm{Pt}(\mathrm{II}), \mathrm{Ag}(\mathrm{I}), \mathrm{Hg}(\mathrm{II})$, $\mathrm{Au}(\mathrm{I})$ and $\mathrm{Au}(\mathrm{III})^{13-16}$ and very few examples of $\mathrm{O}$ coordinated ylides, e.g., Sn(IV), Ti(IV) and Hf(IV) ${ }^{17}$ are known. In this study, we describe the preparation, structural and spectroscopic characterization of $\operatorname{Ag}(\mathrm{I})$ complexes with the title ylides. The single crystal X-ray diffraction of $\mathbf{C 1}$ and $\mathbf{C 3}$ demonstrates C-coordination of ylides with metals.

\section{Experimental}

All reactions were performed in nitrogen atmosphere. Methanol was distilled over magnesium powder and diethyl ether was distilled over a mixture of sodium and benzophenone just before use. All other solvents were reagent grade and used without further purification. The ligands were synthesized by the reaction of triphenylphosphine with 2-chloro and 2-bromoactophenones to produce the related phosphonium salts. Further treatment of the salts with aqueous $\mathrm{NaOH}$ solution led to elimination of $\mathrm{H}_{2} \mathrm{O}$ and $\mathrm{NaBr}$, giving free ligands. ${ }^{18-20}$ Melting points were measured on a Stuart SMP3 apparatus. Elemental analysis were performed using a Perkin-Elmer 2400 series analyzer. Fourier transform IR spectra were recorded on a Shimadzu 435-U-04 spectrophotometer and samples were prepared as $\mathrm{KBr}$ pellets. ${ }^{1} \mathrm{H},{ }^{31} \mathrm{P}$ and ${ }^{13} \mathrm{C}$ NMR spectra were recorded on $90 \mathrm{MHz}$ Jeol and $300 \mathrm{MHz}$ Bruker spectrometers.

\section{$2.1 X$-ray crystallography}

The single crystal X-ray diffraction analysis of suitable crystals of $\mathbf{C 1}$ and $\mathbf{C 3}$ were performed on a STOE IPDS-II diffractometer at $298 \mathrm{~K}$, using graphite monochromated Mo $\mathrm{K} \alpha$ radiation $(\lambda=0.71073 \AA)$. Data collection was performed using $\omega$-scan technique and the STOE X-AREA software package. ${ }^{21}$ The crystal structures were solved by direct methods and refined by full-matrix least-squares on $F^{2}$ by SHELX $97^{22}$ and using the X-STEP32 crystallographic software package. ${ }^{23}$

\subsection{Syntheses of $A g(I)$ complexes}

2.2a Syntheses of $\left[(\mathrm{Ll})_{2} \mathrm{Ag}\right] \mathrm{NO}_{3}(\mathrm{Cl}):$ General procedure: To a solution of $\mathrm{AgNO}_{3}(0.06 \mathrm{~g}, 0.38 \mathrm{mmol})$ in methanol $(20 \mathrm{ml})$ was added $\mathbf{L} \mathbf{1}(0.3 \mathrm{~g}, 0.76 \mathrm{mmol})$ and stirred for $10 \mathrm{~h}$. The solution was protected from light with aluminium foil. A colourless product formed by slow evaporation of the solvent and concentration to $3 \mathrm{ml}$. The product was washed several times with petroleum ether $(3 \times 10 \mathrm{ml})$. Yield: $0.266 \mathrm{~g}(74 \%)$. Anal. Calc. for $\mathrm{C}_{54} \mathrm{H}_{46} \mathrm{AgNO}_{5} \mathrm{P}_{2}$ : C 67.64; $\mathrm{H}$ 4.83; N 1.46\%. found: C 67.32; H 5.13; N 1.28\%. Melting point: $186-187^{\circ} \mathrm{C}$. FT-IR $\left(\mathrm{KBr}, \mathrm{cm}^{-1}\right): 1598(\mathrm{CO}), 863$ (P-C). ${ }^{1} \mathrm{H}$ NMR $\left(\mathrm{CDCl}_{3}, \delta \mathrm{ppm}\right): 2.27\left(\mathrm{~s}, 3 \mathrm{H}, \mathrm{CH}_{3}\right)$, $5.19\left(\mathrm{~d}, 1 \mathrm{H}, \mathrm{CH},{ }^{2} J=8.69 \mathrm{~Hz}\right), 6.98-7.91(\mathrm{~m}, 19 \mathrm{H}$, arom.). ${ }^{31} \mathrm{P}$ NMR $\left(\mathrm{CDCl}_{3}, \delta \mathrm{ppm}\right): 21.72 .{ }^{13} \mathrm{C} \mathrm{NMR}$ $\left(\mathrm{CDCl}_{3}, \delta \mathrm{ppm}\right): 20.74\left(\mathrm{~s}, \mathrm{CH}_{3}\right), 36.65\left(\mathrm{~d}, \mathrm{CH},{ }^{1} J_{\mathrm{PC}}=\right.$ $71.39 \mathrm{~Hz}), 124.23\left(\mathrm{~d},{ }^{1} J_{\mathrm{PC}}=89.86 \mathrm{~Hz}, \mathrm{PPh}_{3}(\mathrm{i})\right)$; $132.25\left(\mathrm{~d},{ }^{2} J_{\mathrm{PC}}=8.83 \mathrm{~Hz}, \mathrm{PPh}_{3}(\mathrm{o})\right) ; 128.61\left(\mathrm{~d},{ }^{3} J_{\mathrm{PC}}=\right.$ $\left.12.57 \mathrm{~Hz}, \mathrm{PPh}_{3}(\mathrm{~m})\right) ; 134.38\left(\mathrm{~d},{ }^{4} J_{\mathrm{PC}}=10.31 \mathrm{~Hz}, \mathrm{PPh}_{3}\right.$ (p)); 141.23 (s, COPh(i)); 132.05 (s, COPh(o)); 126.89 (s, COPh(m)); 128.33 (s, COPh(p)); 190.30 (s, CO).

2.2b Data for [( 22$)_{2} \mathrm{Ag}_{1 \mathrm{NO}_{3}}$ (C2): Yield: $0.216 \mathrm{~g}$ (65\%). Anal. Calc. for $\mathrm{C}_{52} \mathrm{H}_{40} \mathrm{AgBr}_{2} \mathrm{NO}_{5} \mathrm{P}_{2}$ : C 57.38; $\mathrm{H} 3.70 ; \mathrm{N} 1.29 \%$. found: C 57.31; H 3.42; N 1.21\%. Melting point: $202-204^{\circ} \mathrm{C}$. FT-IR $\left(\mathrm{KBr}, \mathrm{cm}^{-1}\right): 1613$ (CO), 855 (P-C). ${ }^{1} \mathrm{H}$ NMR $\left(\mathrm{CDCl}_{3}, \delta\right.$ ppm): 5.25 (br, $1 \mathrm{H}, \mathrm{CH}), 7.04-7.86(\mathrm{~m}, 19 \mathrm{H}$, arom $) .{ }^{31} \mathrm{P} \mathrm{NMR}\left(\mathrm{CDCl}_{3}\right.$, $\delta \mathrm{ppm}): 21.45 .{ }^{13} \mathrm{C} \mathrm{NMR}\left(\mathrm{CDCl}_{3}, \delta \mathrm{ppm}\right): 36.54(\mathrm{~d}$, $\left.\mathrm{CH},{ }^{1} J_{\mathrm{PC}}=72.10 \mathrm{~Hz}\right), 123.89\left(\mathrm{~d},{ }^{1} J_{\mathrm{PC}}=89.24 \mathrm{~Hz}\right.$, $\left.\mathrm{PPh}_{3}(\mathrm{i})\right) ; 133.16\left(\mathrm{~d},{ }^{2} J_{\mathrm{PC}}=8.54 \mathrm{~Hz}, \mathrm{PPh}_{3}(\mathrm{o})\right) ; 128.14$ $\left(\mathrm{d},{ }^{3} J_{\mathrm{PC}}=13.72 \mathrm{~Hz}, \mathrm{PPh}_{3}(\mathrm{~m})\right) ; 135.46\left(\mathrm{~d},{ }^{4} J_{\mathrm{PC}}=\right.$ $11.30 \mathrm{~Hz}, \mathrm{PPh}_{3}$ (p)); 137.42 (s, COPh(i)); 131.54 (s, $\mathrm{COPh}(\mathrm{o})) ; 127.16(\mathrm{~s}, \mathrm{COPh}(\mathrm{m})) ; 129.0(\mathrm{~s}, \mathrm{COPh}(\mathrm{p}))$; 191.17 (s, CO).

2.2c Data for $\left[\left(L_{3}\right)_{2} \mathrm{Ag}\right] \mathrm{NO}_{3}$ (C3): Yield: $0.231 \mathrm{~g}$ (77\%). Anal. Calc. for $\mathrm{C}_{52} \mathrm{H}_{40} \mathrm{AgCl}_{2} \mathrm{NO}_{5} \mathrm{P}_{2}: \mathrm{C} 62.47$; $\mathrm{H} 4.03$; N 1.40\%. found: C 62.12; H 4.41; N $1.62 \%$. Melting point: $196-199^{\circ} \mathrm{C}$. FT-IR $\left(\mathrm{KBr}, \mathrm{cm}^{-1}\right): 1609$ (CO), 861 (P-C). ${ }^{1} \mathrm{H}$ NMR $\left(\mathrm{CDCl}_{3}, \delta\right.$ ppm): 5.19 (br, $1 \mathrm{H}, \mathrm{CH}), 7.14-8.00$ (m, $19 \mathrm{H}$, arom). ${ }^{31} \mathrm{P} \mathrm{NMR}\left(\mathrm{CDCl}_{3}\right.$, $\delta$ ppm): $21.15 .{ }^{13} \mathrm{C} \mathrm{NMR}\left(\mathrm{CDCl}_{3}, \delta \mathrm{ppm}\right): 37.68(\mathrm{~d}$, $\left.\mathrm{CH},{ }^{1} J_{\mathrm{PC}}=74.07 \mathrm{~Hz}\right), 124.49\left(\mathrm{~d},{ }^{1} J_{\mathrm{PC}}=89.90 \mathrm{~Hz}\right.$, $\left.\mathrm{PPh}_{3}(\mathrm{i})\right) ; 132.52\left(\mathrm{~d},{ }^{2} J_{\mathrm{PC}}=9.16 \mathrm{~Hz}, \mathrm{PPh}_{3}(\mathrm{o})\right) ; 128.88$ $\left(\mathrm{d},{ }^{3} J_{\mathrm{PC}}=12.32 \mathrm{~Hz}, \mathrm{PPh}_{3}(\mathrm{~m})\right) ; 135.96\left(\mathrm{~d},{ }^{4} J_{\mathrm{PC}}=\right.$ $10.92 \mathrm{~Hz}, \mathrm{PPh}_{3}$ (p)); 137.00 (s, COPh(i)); 132.31 (s, $\mathrm{COPh}(\mathrm{o})$ ); 127.91 (s, $\mathrm{COPh}(\mathrm{m})) ; 128.60$ (s, $\mathrm{COPh}(\mathrm{p})$ ); 189.05 (s, CO).

2.2d Data for $\left[\left(L_{4}\right)_{2} \mathrm{Ag} \mathrm{NO}_{3}\right.$ (C4): Yield: $0.213 \mathrm{~g}$ (71\%). Anal. Calc. for $\mathrm{C}_{52} \mathrm{H}_{40} \mathrm{AgN}_{3} \mathrm{O}_{9} \mathrm{P}_{2}$ : C 61.18; $\mathrm{H}$ 3.95; N 4.11\%; found: C 61.49; H 4.35; N 4.31\%. Melting point: $196-199^{\circ} \mathrm{C}$. FT-IR $\left(\mathrm{KBr}, \mathrm{cm}^{-1}\right): 1618(\mathrm{CO})$, 872 (P-C). ${ }^{1} \mathrm{H}$ NMR $\left(\mathrm{CDCl}_{3}, \delta\right.$ ppm): 5.15 (d, $1 \mathrm{H}, \mathrm{CH}$, ${ }^{2} J=8.24 \mathrm{~Hz}$ ), 7.24-8.09 (m, 19H, arom.). ${ }^{31} \mathrm{P}$ NMR $\left(\mathrm{CDCl}_{3}, \delta \mathrm{ppm}\right): 20.75 .{ }^{13} \mathrm{C} \mathrm{NMR}\left(\mathrm{CDCl}_{3}, \delta \mathrm{ppm}\right)$ : $40.33\left(\mathrm{~d}, \mathrm{CH},{ }^{1} J_{\mathrm{PC}}=80.65 \mathrm{~Hz}\right), 124.48\left(\mathrm{~d},{ }^{1} J_{\mathrm{PC}}=\right.$ 
$\left.90.08 \mathrm{~Hz}, \mathrm{PPh}_{3}(\mathrm{i})\right) ; 132.82\left(\mathrm{~d},{ }^{2} J_{\mathrm{PC}}=9.88 \mathrm{~Hz}, \mathrm{PPh}_{3}\right.$ (o)); $129.22\left(\mathrm{~d},{ }^{3} J_{\mathrm{PC}}=12.66 \mathrm{~Hz}, \mathrm{PPh}_{3}(\mathrm{~m})\right) ; 128.33$ $\left(\mathrm{s}, \mathrm{PPh}_{3}(\mathrm{p})\right) ; 143.23\left(\mathrm{~d},{ }^{3} J_{\mathrm{PC}}=11.60 \mathrm{~Hz}, \mathrm{COPh}(\mathrm{i})\right)$; 133.04 (s, $\operatorname{COPh}(\mathrm{o})) ; 123.12$ (s, COPh$(\mathrm{m})) ; 149.15$ (s, $\mathrm{COPh}(\mathrm{p})) ; 187.73$ (s, CO).

2.2e Data for $\left[\left(L_{5}\right)_{2} \mathrm{Ag}\right] \mathrm{NO}_{3}$ (C5): Yield: $0.242 \mathrm{~g}$ (68\%). Anal. Calc. for $\mathrm{C}_{54} \mathrm{H}_{46} \mathrm{AgNO}_{7} \mathrm{P}_{2}$ : C 66.54; $\mathrm{H}$ 4.76; N 1.44\%. found: $\mathrm{C} 66.32 ; \mathrm{H} 4.86 ; \mathrm{N} 1.31 \%$. Melting point: $192-194^{\circ} \mathrm{C}$. FT-IR $\left(\mathrm{KBr}, \mathrm{cm}^{-1}\right): 1583$ (CO), 852 (P-C). ${ }^{1} \mathrm{H}$ NMR $\left(\mathrm{CDCl}_{3}, \delta \mathrm{ppm}\right): 3.89$ (s, $\left.3 \mathrm{H}, \mathrm{CH}_{3}\right), 5.33\left(\mathrm{~d}, 1 \mathrm{H}, \mathrm{CH},{ }^{2} \mathrm{~J}=9.25 \mathrm{~Hz}\right)$ and $6.93-$ 7.72 (m, 19H, arom.). ${ }^{31} \mathrm{P} \mathrm{NMR}\left(\mathrm{CDCl}_{3}, \delta \mathrm{ppm}\right): 22.13$. ${ }^{13} \mathrm{C}$ NMR $\left(\mathrm{CDCl}_{3}, \delta \mathrm{ppm}\right): 29.62\left(\mathrm{~s}, \mathrm{CH}_{3}\right), 46.28(\mathrm{~d}$, $\left.\mathrm{CH},{ }^{1} J_{\mathrm{PC}}=68.65 \mathrm{~Hz}\right), 123.98\left(\mathrm{~d},{ }^{1} J_{\mathrm{PC}}=90.65 \mathrm{~Hz}\right.$, $\mathrm{PPh}_{3}$ (i)); 132.93 (d, $\left.{ }^{2} J_{\mathrm{PC}}=9.32 \mathrm{~Hz}, \mathrm{PPh}_{3}(\mathrm{o})\right) ; 127.98$ $\left(\mathrm{d},{ }^{3} J_{\mathrm{PC}}=13.52 \mathrm{~Hz}, \mathrm{PPh}_{3}(\mathrm{~m})\right) ; 135.15\left(\mathrm{~d},{ }^{4} J_{\mathrm{PC}}=\right.$ $11.84 \mathrm{~Hz}, \mathrm{PPh}_{3}$ (p)); 140.57 (s, COPh(i)); 131.66 (s, $\mathrm{COPh}(\mathrm{o})$ ); 127.25 (s, $\mathrm{COPh}(\mathrm{m})) ; 128.89$ (s, $\mathrm{COPh}(\mathrm{p})$ ); $188.48 \mathrm{ppm}(\mathrm{s}, \mathrm{CO})$.

\section{Results and discussion}

The reaction of ylides with $\mathrm{AgNO}_{3}$ in 2:1 molar ratios in methanol as solvent yielded mononuclear complexes C1-C5 (scheme 1).

\subsection{Spectral studies}

The $v(\mathrm{CO})$ values, which are sensitive to complexation, occur in the range of $1565-1580 \mathrm{~cm}^{-1}$ in the parent ylides, increase for all complexes (table 1), indicative of coordination of the ylide through carbon. The $v\left(\mathrm{P}^{+}-\mathrm{C}^{-}\right)$, which is also diagnostic for coordination, occur in the range of $870-900 \mathrm{~cm}^{-1}$ in $\mathbf{L 1 - L 5}$, shifted to lower frequencies for complexes suggesting removal of electron density in the $\mathrm{P}-\mathrm{C}$ bond. ${ }^{24}$

The IR and ${ }^{1} \mathrm{H}$ NMR data for all complexes are listed in table 1. The methine proton was broad for $\mathbf{C 2}$ and C3. Compounds wherein the ylide is C-coordinated exhibit a ${ }^{2} J_{\mathrm{PH}}$ value of $10 \mathrm{~Hz}$ or less. ${ }^{11}$ The ${ }^{31} \mathrm{P}$ NMR

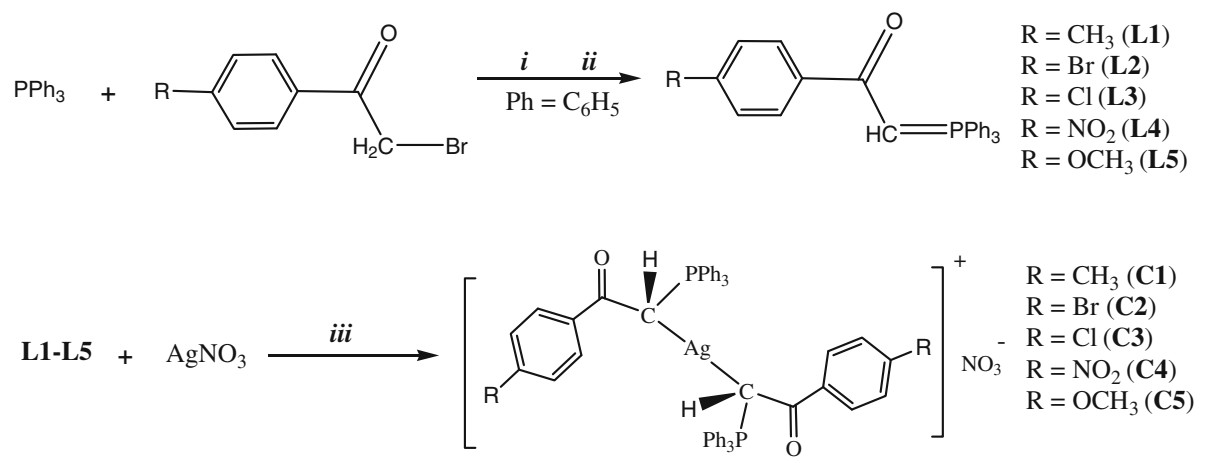

Scheme 1. Synthetic route for preparation of $\mathrm{Ag}(\mathrm{I})$ complexes. In order to ease the visualization of the reactions, letter $\mathrm{R}$ refers to the substituent on para positions of the phenyl. Reagents and conditions: $(i)$ in acetone, using dry nitrogen atmosphere, $4 \mathrm{~h}$ at room temperature (RT); (ii) in $\mathrm{NaOH}$ in water, $2 \mathrm{~h}$ in $40^{\circ} \mathrm{C}$; (iii) in methanol, using aluminium foil to protect from light, $10 \mathrm{~h}$ at RT.

Table 1. IR $\left(\mathrm{cm}^{-1}\right),{ }^{1} \mathrm{H}$ and ${ }^{31} \mathrm{P}$ NMR $[\delta(\mathrm{ppm}), J(\mathrm{~Hz})]$ spectral data.

\begin{tabular}{lccccc}
\hline Complexes & $v(\mathrm{C}=\mathrm{O})$ & $v(\mathrm{P}-\mathrm{C})$ & $\delta_{\mathrm{PCH}}$ & ${ }^{2} J_{\mathrm{PH}}$ & $\delta_{\mathrm{PPh} 3}$ \\
\hline C1 & 1598 & 863 & $5.19(\mathrm{~d})$ & 8.69 & $21.72(\mathrm{~s})$ \\
C2 & 1613 & 855 & $5.25(\mathrm{br})$ & - & $21.45(\mathrm{~s})$ \\
C3 & 1609 & 861 & $5.19(\mathrm{br})$ & - & $21.15(\mathrm{~s})$ \\
C4 & 1678 & 872 & $5.15(\mathrm{~d})$ & 8.24 & $20.75(\mathrm{~s})$ \\
C5 & 1583 & 852 & $5.33(\mathrm{~d})$ & 9.25 & $22.13(\mathrm{~s})$
\end{tabular}

s, singlet; d, doublet; br, broad

$T=298 \mathrm{~K}$; Tetramethylsilane (TMS) $\delta=0.00 \mathrm{ppm}$; shifts relative to internal TMS and external $85 \%$ phosphoric acid 
resonances occur at lower field with respect to free ylide. The expected downfield shifts of ${ }^{1} \mathrm{H}$ and ${ }^{31} \mathrm{P}$ signals for the $\mathrm{PCH}$ group upon complexation were observed. The appearance of single signals for the $\mathrm{PCH}$ group in both the ${ }^{31} \mathrm{P}$ and ${ }^{1} \mathrm{H}$ spectra at ambient temperature indicates the presence of only one resonance for all the complexes as expected for C-coordination; $\mathrm{O}$-coordination of the ylide sometimes leads to formation of cis- and trans-isomers giving rise to two different signals in the ${ }^{31} \mathrm{P}$ and ${ }^{1} \mathrm{H}$ NMR. ${ }^{13}$ Although two diastereoisomers (RR/SS and RS) are possible for silver complexes (because the methine carbons are chiral), NMR spectroscopy does not distinguish them at room temperature. Methine resonances are intermediate between, and ${ }^{2} J_{\mathrm{PH}}$ values smaller than, those in the free ylides and phosphonium salts ${ }^{19,20}$ as observed for other C-coordinated carbonyl-stabilized phosphorus ylide complexes, due to hybridization change in the ylidic carbon $\left(\mathrm{sp}^{2}-\mathrm{sp}^{3}\right)$ with C-coordination. ${ }^{6,11,13}$ Much larger values of ${ }^{2} J_{\mathrm{PH}}$ (ca. $20 \mathrm{~Hz}$ ) have been observed in complexes where coordination is through the oxygen. ${ }^{25}$ Neither $\mathrm{H}-\mathrm{Ag}$ nor $\mathrm{P}-\mathrm{Ag}$ coupling was observed at room temperature in the spectra, possibly a fast equilibrium between complexes and free ylides is responsible for the failure to observe NMR coupling or two diastereoisomers.

The most interesting aspect of the ${ }^{13} \mathrm{C}$ NMR spectra of the complexes is the upfield shift of the signals due to the ylidic carbon. Such an upfield shift observed in $\operatorname{PdCl}\left(\eta^{3}-2-\mathrm{XC}_{3} \mathrm{H}_{4}\right)\left(\mathrm{C}_{6} \mathrm{H}_{5}\right)_{3} \mathrm{PCHCOR}\left(\mathrm{X}=\mathrm{H}, \mathrm{CH}_{3}\right.$; $\left.\mathrm{R}=\mathrm{CH}_{3}, \mathrm{C}_{6} \mathrm{H}_{5}\right)$ was attributed to the change in hybridization of the ylidic carbon. ${ }^{26}$ The ${ }^{13} \mathrm{C}$ shifts of the $\mathrm{CO}$ group in the complexes are around $190 \mathrm{ppm}$, relative to $\sim 180 \mathrm{ppm}$ noted for the same carbon in the parent ylide, indicating much lower shielding of the carbon of the $\mathrm{CO}$ group in these complexes.

Table 2. Crystal and experimental data.

\begin{tabular}{|c|c|c|}
\hline Compound & C1 & $\mathbf{C 3}$ \\
\hline Chemical formula & $\mathrm{C}_{54} \mathrm{H}_{46} \mathrm{Ag}_{1} \mathrm{~N}_{1} \mathrm{O}_{5} \mathrm{P}_{2}$ & $\mathrm{C}_{52} \mathrm{H}_{40} \mathrm{Ag}_{1} \mathrm{Cl}_{2} \mathrm{~N}_{1} \mathrm{O}_{5} \mathrm{P}_{2}$ \\
\hline Formula weight & 958.73 & 999.56 \\
\hline Temperature $(\mathrm{K})$ & $120(2) \mathrm{K}$ & $120(2) \mathrm{K}$ \\
\hline Crystal system & Triclinic & Triclinic \\
\hline Space group & $P-1$ & $P-1$ \\
\hline$a(\AA)$ & $10.6372(3)$ & $10.5500(4)$ \\
\hline$b(\AA)$ & $13.2466(4)$ & $13.1609(4)$ \\
\hline$c(\AA)$ & $18.3250(5)$ & 17.7761(6) \\
\hline$\alpha\left(^{\circ}\right)$ & $80.536(2)$ & $79.041(3)$ \\
\hline$\beta\left(^{\circ}\right)$ & $77.079(2)$ & $77.216(3)$ \\
\hline$\gamma\left({ }^{\circ}\right)$ & $79.418(3)$ & $77.474(3)$ \\
\hline Volume $\left(\AA^{3}\right)$ & $2453.34(12)$ & $2323.36(14)$ \\
\hline$Z$ & 2 & 2 \\
\hline$D_{\mathrm{x}}\left(\mathrm{Mg} / \mathrm{m}^{3}\right)$ & 1.298 & 1.429 \\
\hline Wavelength $(\AA)$ & 0.71073 & 0.71073 \\
\hline$\mu\left(\operatorname{Mo~} K_{\alpha}\right)\left(\mathrm{mm}^{-1}\right)$ & 0.523 & 0.666 \\
\hline$F(000)$ & 988 & 1020 \\
\hline Crystal size $\left(\mathrm{mm}^{3}\right)$ & $0.31 \times 0.30 \times 0.25$ & $0.36 \times 0.35 \times 0.25$ \\
\hline Absorption correction & numerical & numerical \\
\hline Maximum and minimum transmission & 0.880 and 0.850 & 0.8607 and 0.7837 \\
\hline No. of reflections collected & 13159 & 26044 \\
\hline No. of independent reflections & 13159 & 12488 \\
\hline$\theta$ range for data collection $\left(^{\circ}\right)$ & 2.30 to 29.17 & 2.13 to 29.21 \\
\hline Data/Restraints/Parameters & $13159 / 0 / 585$ & $12488 / 0 / 568$ \\
\hline Goodness-of-fit on $F^{2}$ & 1.083 & 1.086 \\
\hline$R$ indices $[I>2 \sigma(I)]$ & $R_{1}=0.0556, w R_{2}=0.1229$ & $R_{1}=0.1010, w R_{2}=0.2466$ \\
\hline$R$ indices (all data) & $R_{1}=0.0716, w R_{2}=0.1290$ & $R_{1}=0.1319, w R_{2}=0.2700$ \\
\hline$(\Delta / \rho)_{\max }\left(\mathrm{e}^{-3}\right)$ & 0.753 & 2.033 \\
\hline$(\Delta / \rho)_{\min }\left(\mathrm{e}^{-3}\right)$ & -0.789 & -1.588 \\
\hline Measurement & STOE IPDS II diffractometer & STOE IPDS II diffractometer \\
\hline Programs system & SHELXLS-97 and SHELXL-97 & SHELXLS-97 and SHELXL-97 \\
\hline Refinement method & Full-matrix least-squares on $F^{2}$ & Full-matrix least-squares on $F^{2}$ \\
\hline Cambridge Crystallographic Data & 865649 & 811867 \\
\hline Centre (CCDC) deposition number & & \\
\hline
\end{tabular}


Table 3. Selected key bond lengths $(\AA)$ and angles $\left(^{\circ}\right)$.

\begin{tabular}{|c|c|c|c|}
\hline & $\mathrm{C} 1$ & & C3 \\
\hline Bond lengths ( $($ ) & \multicolumn{3}{|c|}{ Bond lengths $(\AA ̊)$} \\
\hline $\mathrm{Ag} 1-\mathrm{C} 9$ & $2.206(3)$ & $\mathrm{Ag} 1-\mathrm{C} 1$ & $2.197(6)$ \\
\hline Ag1-C36 & 2.194(3) & $\mathrm{Ag} 1-\mathrm{C} 27$ & $2.189(6)$ \\
\hline C35-C36 & $1.463(4)$ & $\mathrm{C} 1-\mathrm{C} 2$ & $1.466(9)$ \\
\hline C8-C9 & $1.454(4)$ & C27-C28 & $1.472(9)$ \\
\hline $\mathrm{C} 8-\mathrm{O} 1$ & $1.238(4)$ & C2-O1 & $1.247(8)$ \\
\hline C35-O2 & $1.242(4)$ & $\mathrm{C} 28-\mathrm{O} 2$ & $1.225(8)$ \\
\hline P1-C9 & $1.761(3)$ & $\mathrm{P} 1-\mathrm{C} 1$ & $1.749(7)$ \\
\hline P2-C36 & $1.754(3)$ & $\mathrm{P} 2-\mathrm{C} 27$ & $1.748(7)$ \\
\hline Bond angles $\left({ }^{\circ}\right)$ & \multicolumn{3}{|c|}{ Bond angles $\left(^{\circ}\right)$} \\
\hline Ag1-C9-C8 & $100.4(2)$ & Ag1-C27-C28 & $100.0(4)$ \\
\hline Ag1-C9-P1 & 108.7(1) & Ag1-C1-P1 & $108.0(3)$ \\
\hline Ag1-C36-C35 & $102.9(2)$ & $\mathrm{Ag} 1-\mathrm{C} 1-\mathrm{C} 2$ & $101.7(4)$ \\
\hline Ag1-C36-P2 & $108.7(1)$ & $\mathrm{Ag} 1-\mathrm{C} 27-\mathrm{P} 2$ & $108.8(3)$ \\
\hline C9-Ag1-C36 & $174.5(1)$ & $\mathrm{C} 1-\mathrm{Ag} 1-\mathrm{C} 27$ & $174.2(2)$ \\
\hline $\mathrm{P} 1-\mathrm{C} 9-\mathrm{C} 8$ & $116.3(2)$ & $\mathrm{P} 1-\mathrm{C} 1-\mathrm{C} 2$ & $115.5(5)$ \\
\hline P2-C36-C35 & $113.6(2)$ & P2-C27-C28 & $117.5(5)$ \\
\hline C9-C8-O1 & $121.8(3)$ & $\mathrm{C} 1-\mathrm{C} 2-\mathrm{O} 1$ & $119.9(6)$ \\
\hline C36-C35-O2 & 113(3) & $\mathrm{C} 27-\mathrm{C} 28-\mathrm{O} 2$ & $122.2(6)$ \\
\hline C7-C8-C9 & 119.1(3) & $\mathrm{C} 1-\mathrm{C} 2-\mathrm{C} 3$ & $119.8(6)$ \\
\hline C34-C35-C36 & 119.7(3) & C27-C28-C29 & $118.1(5)$ \\
\hline
\end{tabular}

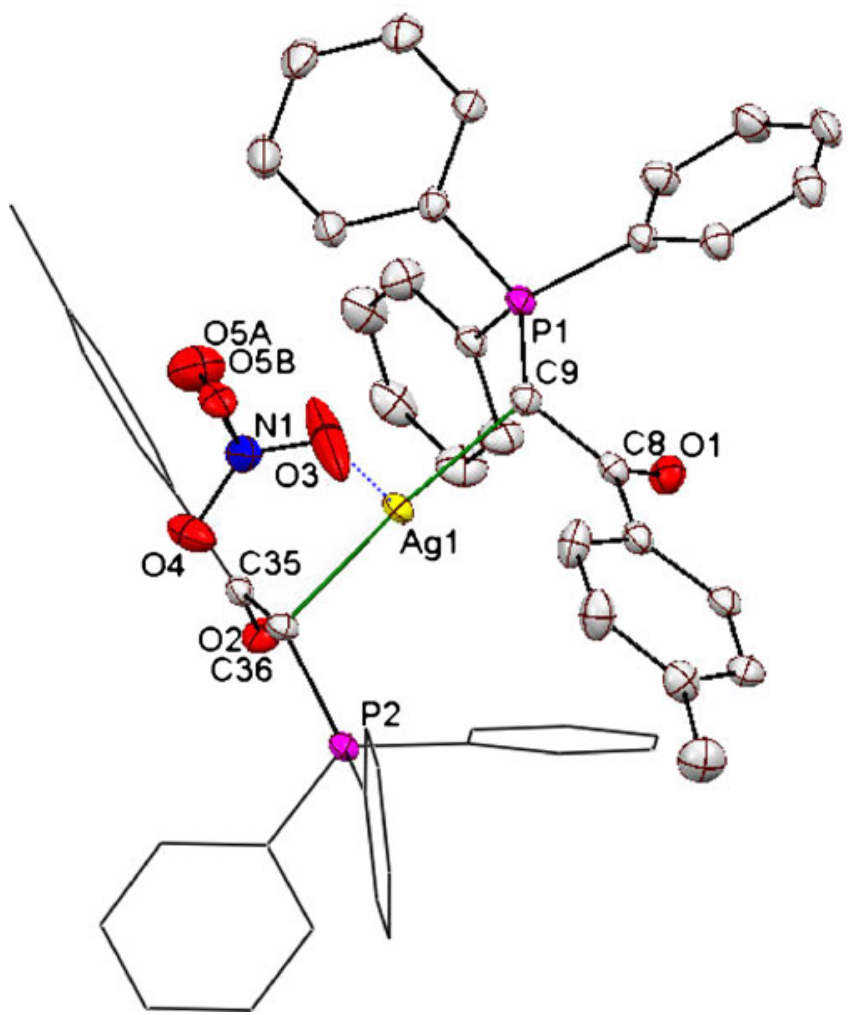

Figure 1. Molecular structure drawing of $\mathbf{C 1}$ with the selected atom-numbering scheme. Hydrogen atoms are omitted for clarity. Displacement ellipsoids are drawn at 50\% probability level. For the molecular structure of $\mathbf{C 1}$, one nitrate oxygen atom is highly disordered and it is split into two positions with $50 \%$ occupancy (O5A-O5B).

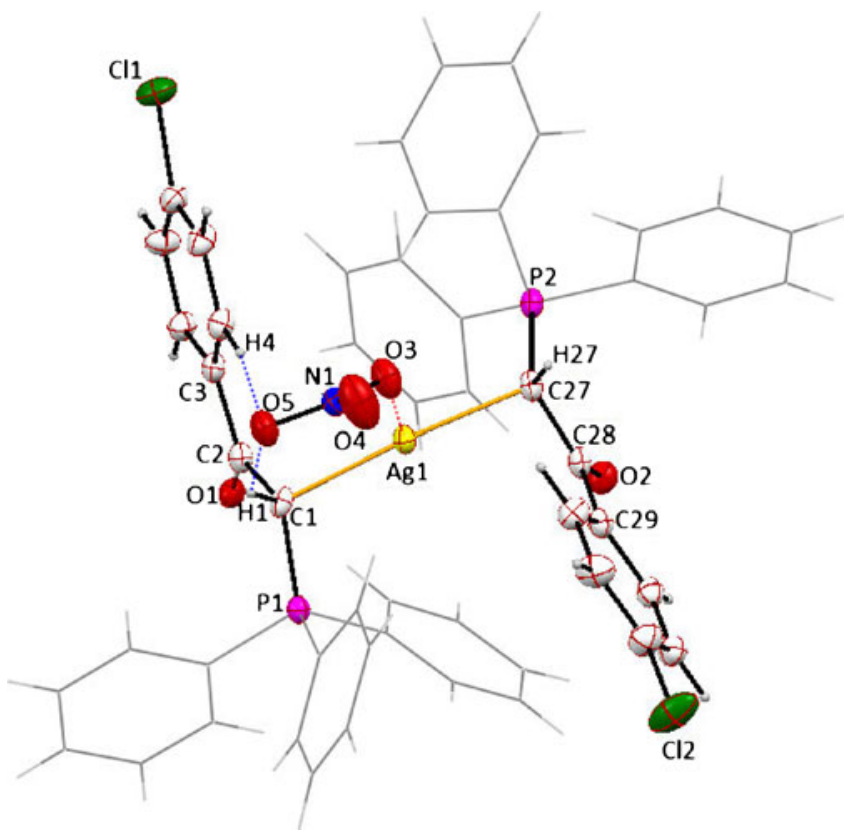

Figure 2. Molecular structure drawing of $\mathbf{C 3}$ with the selected atom-numbering scheme. Displacement ellipsoids are drawn at $30 \%$ probability level.

\subsection{Description of the crystal structures}

All crystallographic details of $\mathbf{C 1}$ and $\mathbf{C 3}$ are in table 2 and significant bond distances and angles are collected 


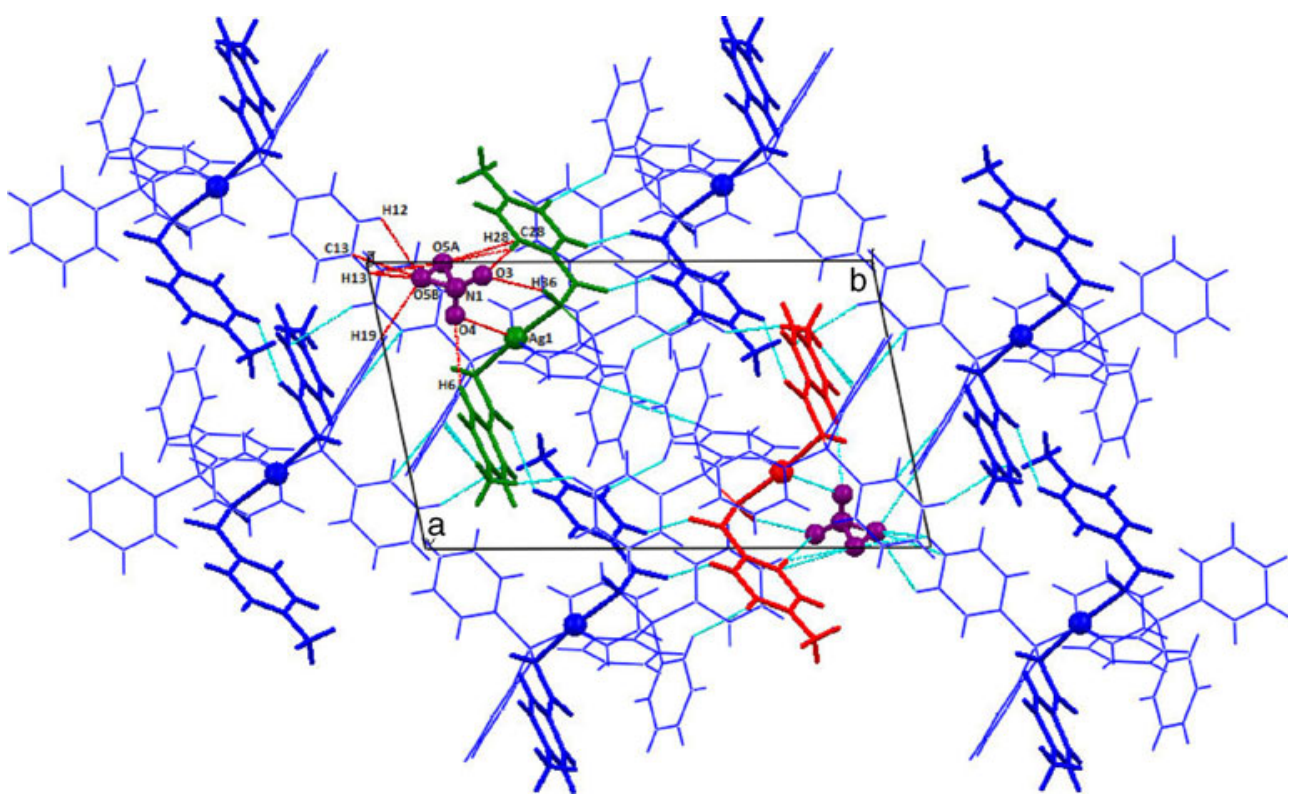

Figure 3. A packing representation of complex $\mathbf{C 1}$ showing the association of the adjacent molecules through C-Hphenyl... $\pi$-phenyl, C-Hphenyl...O-carbonyl, C-Hphenyl...Onitrate, C-Hmethine...Onitrate, Onitrate... Ag, and C-Hphenyl...Onitrate interactions. Dotted lines represent the short contacts.

in table 3. Molecular structures of $\mathbf{C 1}$ and $\mathbf{C 3}$ are shown in figures 1 and 2, respectively. Crystals of $\mathbf{C 1}$ were obtained by slow diffusion of $n$-hexane into $\mathrm{CHCl}_{3}$ solution at room temperature. Also, crystals of $\mathbf{C} 3$ were obtained by slow diffusion of $\mathrm{EtO}_{2}$ into $\mathrm{CHCl}_{3}$ solution at room temperature.

The relative configuration at the chiral carbon atoms is RR. The $\operatorname{Ag}(\mathrm{I})$ atom is located in a slightly distorted linear environment, surrounded by $\mathbf{C}$ atoms of the methine of the ylide. The configuration about the molecular axis $\{\mathrm{C}(9) \ldots \mathrm{C}(36)$ and $(\mathrm{C}(1) \ldots \mathrm{C}(27)\}$ is almost eclipsed (figures 1 and 2). The coordination geometry at silver is essentially linear, although bond lengths and angles at silver are slightly distorted $\left\{\mathrm{C}(9)-\mathrm{Ag}-\mathrm{C}(36)=171.3(1)^{\circ}\right.$ and $\mathrm{C}(1)-\mathrm{Ag}-$ $\left.\mathrm{C}(27)=174.2(2)^{\circ}\right\}$. The $\mathrm{P}(1)-\mathrm{C}(9)$ (methine) distance in $\mathbf{C 1}$ and the $\mathrm{P}(1)-\mathrm{C}(1)$ distance in $\mathbf{C 3}$ are 1.761(3) and $1.749(7) \AA$, respectively, shorter than the average $\mathrm{P}-\mathrm{C}(\mathrm{Ph})$ single bond distance $(1.807 \AA)$, indicating some multiple bond character. ${ }^{3,27}$ For comparison, the $\mathrm{P}-\mathrm{C}$ bond distance in $\mathrm{Ph}_{3} \mathrm{PCH}_{2}$ is $1.66 \AA$, which corresponds to a bond order of $1.33 .{ }^{27-29}$ The $\mathrm{C}(8)-\mathrm{C}(9)$ distance in $\mathbf{C 1}$ and the $\mathrm{C}(1)-\mathrm{C}(2)$ distance in $\mathbf{C 3}$ are 1.454(4) and 1.466(9) $\AA$, respectively, indicating single bond character. The $\mathrm{C}(8)-\mathrm{O}(1)$ distance in $\mathbf{C 1}$ and the $\mathrm{C}(2)-\mathrm{O}(1)$ distance in $\mathbf{C 3}$ are 1.238(4) and 1.247(8) $\AA$, respectively, similar to $\mathrm{C}-\mathrm{O}$ bond distances found in C-bond ylides. ${ }^{30-33}$ All complexes are examples of an ylide C-bond to a soft metal centre.

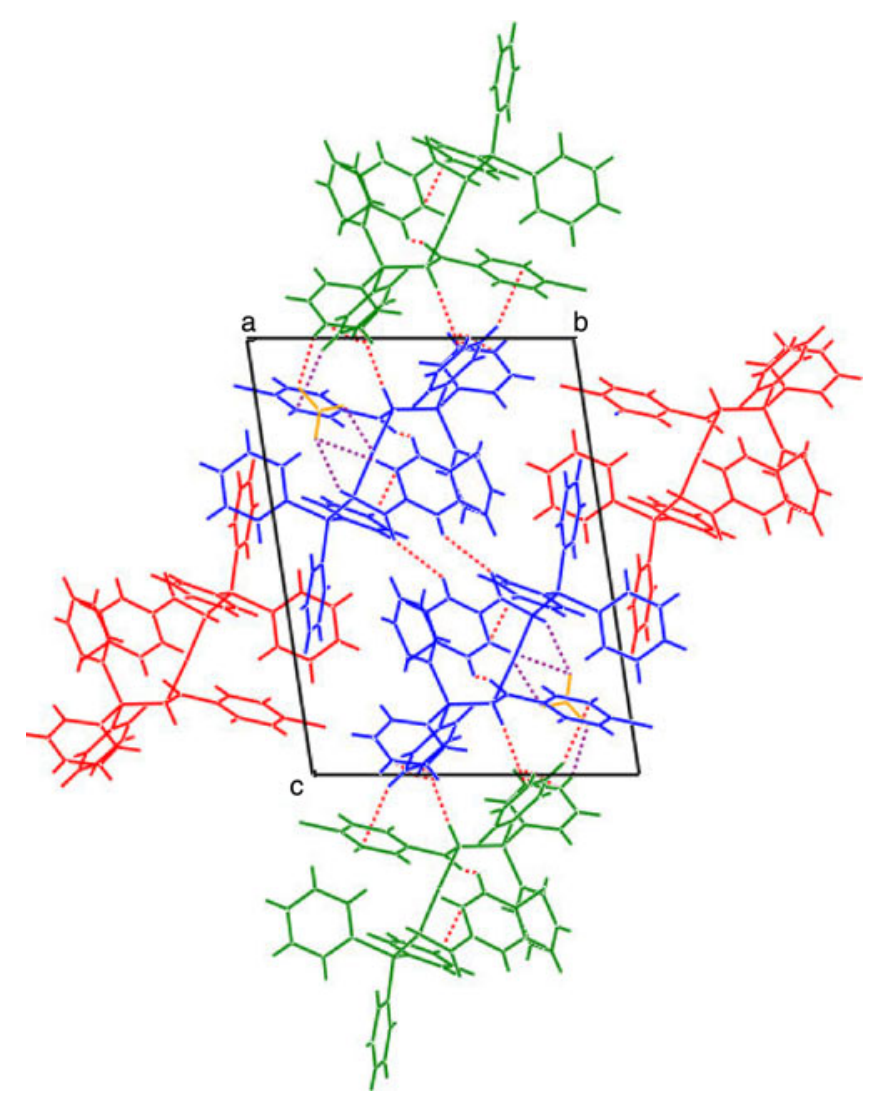

Figure 4. A packing representation of complex C3 showing the association of adjacent molecules through C-Hphenyl... $\pi$ phenyl, C-Hphenyl...Ocarbonyl, C-Hphenyl... Onitrate, C-Hmethine...Onitrate, and Onitrate... Ag interactions. Dotted lines represent the short contacts. Different colours show different adjacent molecules. 
Table 4. Significant C-H... O non-classical hydrogen bonds (interatomic distance $(\AA)$ and bond angles $\left({ }^{\circ}\right)$ ) found in the structures of $\mathbf{C 1}$ and $\mathbf{C 3}$.

\begin{tabular}{|c|c|c|c|c|c|}
\hline D-H...A & $\mathrm{D}-\mathrm{H}$ & H...A & D...A & D-H..A & Symmetry code \\
\hline \multicolumn{6}{|l|}{ Complex $\mathbf{C 1}$} \\
\hline C6-H6... O3 & 0.930 & 2.600 & $3.476(6)$ & 158 & - \\
\hline C27-H27... 1 & 0.930 & 2.500 & $3.326(5)$ & 148 & - \\
\hline C28-H28... O4 & 0.930 & 2.540 & $3.461(5)$ & 173 & - \\
\hline $\mathrm{C} 28-\mathrm{H} 28 \ldots \mathrm{O} 5 \mathrm{~A}$ & 0.930 & 2.570 & $3.176(8)$ & 123 & - \\
\hline C36-H36... O4 & $1.02(6)$ & $2.55(5)$ & $3.484(4)$ & $151(4)$ & - \\
\hline C40-H40... O4 & 0.93 & 2.50 & $3.326(5)$ & 148 & $2-x, 2-y, 1-z$ \\
\hline \multicolumn{6}{|l|}{ Complex C3 } \\
\hline C1-H1... O5 & 0.980 & 2.590 & $3.420(9)$ & 143 & - \\
\hline C4-H4 ... O5 & 0.930 & 2.510 & $3.428(8)$ & 170 & - \\
\hline C8-H8... 1 & 0.930 & 2.440 & $3.223(9)$ & 141 & $2-\mathrm{x}, 2-\mathrm{y}, 1-\mathrm{z}$ \\
\hline C26-H26... O1 & 0.930 & 2.290 & $3.071(9)$ & 141 & - \\
\hline C36-H36... 2 & 0.930 & 2.930 & $3.132(9)$ & 144 & - \\
\hline C50-H50... O4 & 0.930 & 2.930 & $3.463(12)$ & 158 & $1-\mathrm{x}, 1-\mathrm{y}, 2-\mathrm{z}$ \\
\hline
\end{tabular}

\subsection{Intermolecular interactions}

In complexes $\mathbf{C 1}$ and $\mathbf{C 3}$, a combination of several weak and medium intermolecular interactions, determine the structural assembly in this compound (figures 3 and 4, table 4).

The $\mathrm{Ag}(1) \cdots . \mathrm{O}(3)$ distances in $\mathbf{C 1}$ and $\mathbf{C 3}$ are 2.760 and $2.748 \AA$, respectively (figures 2 and 3 ). In fact, the crystal structure of the complexes show a close association between the nitrate anion and the metal centre, with Ag..... distances of 2.76 and $2.75 \AA .{ }^{11}$ For the structure of C1, nitrate oxygen atom is highly disordered and is split into two positions with $50 \%$ occupancy (O5A-O5B).

\section{Conclusions}

The present study describes very simple and efficient synthesis and characterization of two linear $\mathrm{Ag}$ (I) complexes. On the basis of the physicochemical and spectroscopic data, we have proposed that ligands employed here exhibit a linear coordination behaviour to the metal centre. The metal centre is coordinated by two phosphorus ylides via ylidic carbon atom and one $\mathrm{NO}_{3}$ ion. For two of them, $\mathbf{C 1}$ and $\mathbf{C 3}$, the crystal structures had the expected typical structure for linear silver(I) complexes.

\section{Supplementary data}

CCDC 865649 and 811867 contain supplementary crystallographic data for the compounds $\mathbf{C 1}$ and $\mathbf{C 3}$, respectively. These data can be obtained free of charge via http://www.ccdc.cam.ac.uk/conts/retrieving.html or from the Cambridge Crystallographic Data Center, 12 Union Road, Cambridge CB2 1EZ, UK; fax: (+44) 1223-336-033; or e-mail: deposit@ccdc.cam.ac.uk.

\section{References}

1. Christau H J 1994 Chem. Rev. 941299

2. Kolodiazhnyi O I 1996 Tetrahedron 521855

3. Yamamoto Y and Schmidbaur H 1975 J. Organomet. Chem. 9743

4. Schmidbaur H, Zybill C E, Müller G and Kruger C 1983 Angew. Chem. Int. Ed. Engl. 22729

5. Yamamoto Y and Schmidbaur H 1975 J. Organomet. Chem. 96133

6. Schmidbaur H, Adlkofer J and Heimann H 1974 Chem. Ber. 1073697

7. Schmidbaur H, Adlkofer J and Buchner W 1973 Angew. Chem. Int.Ed. Engl. 12415

8. Schmidbaur H and Scherm H P 1977 Chem. Ber. 110 1576

9. Schmidbaur H and Richter W 1975 Chem. Ber. 1082656

10. Vicente J, Chicote M T, Femandez-Baeza J, Martin J, Saura-Llamas I, Turpin J and Jones P G $1987 \mathrm{~J}$. Organomet. Chem. 331409

11. Vicente J, Chicote M T, Saura-Llamas I and Turpin J 1993 J. Chem. Edu. 70163

12. Albanese J A, Rheingold A L and Burmeister J L 1988 Inorg. Chim. Acta $\mathbf{1 5 0} 213$

13. Uson R, Fornies J, Navarro R, Espinet $\mathrm{P}$ and Mendivil C 1985 J. Organomet. Chem. 290125

14. Koezuka H, Matsubayashi G and Tanaka T 1976 Inorg. Chem. 25417

15. Kalyanasundari M, Panchanatheswaran K, Robinson W T and Wen H 1995 J. Organomet. Chem. 91103 
16. Vicente J, Chicote M T, Saura-Llamas I, Turpin J, Fernandez-Baeza J and Cambridge D E C 1995 Phosphorus an outline of chemistry, biochemistry and uses, Amsterdam: Elsevier, 5p

17. Albanese J A, Staley D L, Rheingold A L and Burmeister J L 1990 Inorg. Chem. 292209

18. Ramirez F and Dershowitz S 1957 J. Organomet. Chem. 2241

19. Nesmeyanov N A, Binshtok E V and Reutov O A 1971 Chem. Russ. 1981102

20. Sabounchei S J, Nemattalab H and Jodaian V 2008 Chin. Chem. Soc. 551

21. Stoe\&Cie $2005 \mathrm{X}$-AREA, Version 1.30, program for the acquisition and analysis of data, Stoe\&Cie $\mathrm{GmbH}$, Darmstadt, Germany

22. Sheldrick G M 1997 SHELX97, program for crystal structure solution and refinement, University of Göttingen, Germany

23. Stoe\&Cie $2005 \mathrm{X}-\mathrm{STEP} 32$, Version $1.07 \mathrm{~b}$, crystallographic package, Stoe\&Cie GmbH, Darmstadt, Germany
24. Onishi M, Ohama Y, Hiraki K and Shintan H 1982 Polyhedron 1539

25. Falvello L R, Fernandez S, Navarro R and Urriolabeitia E P 1996 Inorg. Chem. 353064

26. Facchin G, Bertani R, Calligaris M, Nardin G and Mari M 1987 J. Chem. Soc. Dalton Trans. 61381

27. Buckle J, Harrison P G, King T J and Richards J A 1972 J. Chem. Soc. Chem. Commun. 191104

28. Buckle J and Harrison P G 1973 J. Organomet. Chem. 4917

29. Luttke W and Wilhem K 1965 Angew. Chem. 77 867

30. Nishiyama H, Itoh K and Ishii Y 1975 J. Organomet. Chem. 87129

31. Bravo P, Fronza G and Ticozzi T 1976 J. Organomet. Chem. 111361

32. Weleski E T, Silver J L, Jansson M D and Burmeister J L 1975 J. Organomet. Chem. 102365

33. Karami K and Buyukgungor O 2009 J. Coord. Chem. 62 2949 